\title{
Nitrogen balance in paddy fields under flowing-irrigation condition
}

\author{
Makoto Saiki $\cdot$ Thi Phuong Mai Nguyen · Junko Shindo $\cdot$ Kei Nishida
}

Received: 13 February 2019/Accepted: 31 August 2019/Published online: 8 October 2019

(C) The Author(s) 2019, corrected publication 2020

\begin{abstract}
Flowing irrigation which drains a large volume of water is one of agricultural techniques for ensuring rice quality. In this study, the nitrogen input and output were characterised in paddy fields under flowing irrigation based on observation in Central Japan, and the estimated nitrogen loadings were compared to the reported values in traditional paddy fields under stagnant irrigation by using budget analysis. The annual water fluxes in the studied fields were calculated to be more than ten times larger than those in traditional fields. The concentrations of most nitrogen forms in surface drainage and subsurface drainage were detected at highest level during paddling periods, while those of nitrate and nitrite in subsurface drainage increased during non-irrigation periods. The total nitrogen inputs were at upper level (236-332 $\left.\mathrm{kg} \mathrm{N} \mathrm{ha}{ }^{-1}\right)$ of or larger (490-581 $\mathrm{kg} \mathrm{N} \mathrm{ha}^{-1}$ ) than
\end{abstract}

\section{Saiki}

Graduate School of Medicine, Engineering and Agriculture, University of Yamanashi, 4-4-37 Takeda,

Kofu, Yamanashi 400-0016, Japan

T. P. M. Nguyen

Institute of Environmental Technology, Vietnam Academy of Science and Technology, 18 Hoang Quoc

Viet Road, Cau Giay, Hanoi, Vietnam

J. Shindo $\cdot$ K. Nishida $(\bowtie)$

Interdisciplinary Centre for River Basin Environment (ICRE), University of Yamanashi, 4-4-37 Takeda, Kofu, Yamanashi 400-0016, Japan

e-mail: nishida@yamanashi.ac.jp the reported values under both flowing irrigation and stagnant irrigation, and the larger contribution of irrigation pathway was observed. Surface drainage (78.3-163.5 $\mathrm{kg} \mathrm{N} \mathrm{ha}^{-1}$ ) and transport to underground system (73.1-210.4 $\mathrm{kg} \mathrm{N} \mathrm{ha}^{-1}$ ) were significantly higher than reported values obtained from stagnantirrigation paddy fields. The differences between input and output were thereby estimated and the large negative balance was attributed to the soil accumulation, which was distinctly detected in the field with presumably higher adsorption capacity. Therefore, assessing the effect of water flow on soil nitrogen accumulation as well as discharge is recommended by evaluating nitrogen balance in paddy field.

Keywords Rice cultivation - Water pollution · Budget analysis $\cdot$ Soil accumulation

\section{Introduction}

Paddy fields cause nitrogen pollution in surface and subsurface water environments (Cho et al. 2000; Guo et al. 2004; Shinozaka et al. 2016). Nitrogen flow is detected in the paddy fields as several types of inputs or outputs. Inputs include fertiliser, irrigation, precipitation and biological nitrogen fixation, whereas outputs include the assimilation of rice, surface drainage and underground flow, denitrification, volatilisation, assimilation by other plants including 
algae, and accumulation in soil (Takakai et al. 2017; Liang et al. 2007; Antonopoulos 2010). Based on the relation between the amount of applied chemical fertiliser and the loading of nitrogen discharge, Liang et al. (2007) observed increased amount of surface drained nitrogen (5.05, 11.78, 19.25 and $27.86 \mathrm{~kg} \mathrm{~N} \mathrm{ha}^{-1}$ ) and percolated nitrogen (9.07, $18.04,25.00$ and $33.22 \mathrm{~kg} \mathrm{~N}^{-1}$ ) with increase in fertiliser amount $\left(90,180,270\right.$ and $\left.360 \mathrm{~kg} \mathrm{~N}^{-1}\right)$ in an experiment that was conducted in China. In contrast, in Korea, Cho and Han (2002) observed little changes in surface drainage loading $(111,101$ and $129 \mathrm{~kg} \mathrm{~N}$ $\left.\mathrm{ha}^{-1}\right)$ and percolation loading (19, 18 and 20) with increase in applied chemical fertiliser $(155,187$ and $210 \mathrm{~kg} \mathrm{~N} \mathrm{ha}^{-1}$ ). In Japan, Sugimoto et al. (2008) observed that $78 \mathrm{~kg} \mathrm{~N}^{-1}$ of applied fertiliser resulted in surface drainage loading of $41.6 \mathrm{~kg} \mathrm{~N}$ $\mathrm{ha}^{-1}$ that was higher than the value reported by Liang et al. (2007) with similar or higher level of fertilisation. According to these researches, some cases showed that the output loading increased with an increase in input from fertiliser in the same field but others showed that the output was not directly related with the amount of fertiliser when the experimental results in different fields were compared. In addition, it was reported that the nitrogen outputs from paddy fields is dependent on the volume of irrigation water rather than the amount of chemical fertiliser (The Japanese Society of Irrigation, Drainage and Rural Engineering: JSIDRE 2001). The inputs and outputs are not directly connected, and paddy fields exhibit complicated nitrogen bioreactions, including mineralisation, nitrification and denitrification (Ishii et al. 2011). These bioreactions are affected by the physicochemical factors including temperature, $\mathrm{pH}$ and redox conditions in the vicinity of the paddy fields (Chowdary et al. 2004). Thus, to ensure sustainable water environment, it is important to estimate and evaluate the nitrogen loading considering all the processes that occur in paddy fields.

Recently, the budget analysis has been applied to identify the mechanism of nitrogen pollution in the water environment owing to paddy fields (Cho et al. 2000; Liang et al. 2007; Zhang et al. 2013). The nitrogen budget can be used for comprehensively evaluating nitrogen loading by considering multiple inputs and outputs. In majority of the previous studies, however, irrigation, biological fixation, ammonium volatilization, denitrification, assimilation by other plants and accumulation in the soil were rarely evaluated in nitrogen budget estimation. Roger and Ladha (1992) estimated biological $\mathrm{N}_{2}$ fixation using blue-green algae and Azolla in wetland rice fields, which were $0-80$ and $10-50 \mathrm{~kg} \mathrm{~N}$ $\mathrm{ha}^{-1}$ in a rice cropping season, respectively. The contributions of volatilization and denitrification fluctuate responding to various physicochemical factors such as $\mathrm{pH}$ and percolation rate. Antonopoulos (2010) calculated the amount of nitrogen uptake using algae, which resulted in $9.4 \%$ of total input $\mathrm{NH}_{4}-\mathrm{N}$ and $15.7 \%$ of total input $\mathrm{NO}_{3}-\mathrm{N}$. The identification of nitrogen storage in soil is necessary for managing the soil nutrient (Takakai et al. 2017).

In Japan, several agricultural techniques have been developed for improving the rice quality (Morita 2008) and for reducing the loading of nutrients from paddy fields (Haruta et al. 2015). Flowing irrigation has been applied to maintain the ponded water at a low temperature for ensuring high rice quality (Nishida et al. 2015) and to maintain a constant water depth in the paddy fields, where the soil has a high percolation rate (Takeda et al. 1991). A large volume of water is drained in flowing irrigation-type paddy. The results obtained by Yoshinaga et al. (2007) implied that runoff nitrogen was affected more by the irrigation water volume than by the area of the paddy fields. Therefore, the water environment may be notably impacted by the nitrogen discharge under flowing irrigation conditions. However, we have observed only a limited number of reports on nitrogen discharge evaluation (Takeda et al. 1991; Yamazaki et al. 2013; Hama et al. 2015) and, to our knowledge, no report on the nitrogen budget for flowing irrigation paddy fields.

This study intended to characterise the nitrogen input and output in paddy fields under flowing irrigation in Japan. The nitrogen loadings to water environments were estimated based on field observation and then the nitrogen balances were evaluated using budget analysis, and the water-derived nitrogen flow of the flowing irrigation-type paddy fields was compared with the traditional paddy fields under stagnant irrigation-type.

\section{Methodology}

Study area

The study area located at $35.6^{\circ} \mathrm{N} 138.5^{\circ} \mathrm{E}$ in Kai City, Yamanashi Prefecture, Japan, includes two paddy 
fields, E1 (0.11 ha: $37 \times 30 \mathrm{~m}$; soil depth: $55 \mathrm{~cm})$ and W2 (0.11 ha: $33 \times 33 \mathrm{~m}$; soil depth: $10 \mathrm{~cm})$, managed by a farmer (Table 1). This research experiment was conducted from 2013 to 2015 , and the fields were detailed in a previous report (Nguyen et al. 2015). The farmer applied organic fertiliser in early spring only in the first year of our experiment, and chemical fertiliser was used for a basal fertiliser before the first irrigation every year. The water management type of both the fields was flowing irrigation. The irrigation water was supplied to each paddy field continuously through the inlet gate systems from the end of May to the end of September (irrigation period). However, in July, the farmer stopped irrigation for approximately 1 week to dry the soil of the paddy fields. After the final drainage, no irrigation water flew until next spring (nonirrigation period). Further, the ponded water was directly drained from the paddy fields to a ditch though outlets (surface drainage) or was percolated into the soil. The percolated water was partly discharged via pipes installed below the paddy soil (subsurface drainage). E1 had four such outlets for subsurface drainage at depths of 51, 70, 75 and $78 \mathrm{~cm}$ from the soil surface in the rice paddy, and the outlet was at a $77 \mathrm{~cm}$ depth in W2.

Field survey and analysis

The E1 and W2 paddy fields were surveyed at weekly intervals from 21 May, 2013, to 20 December, 2015, and at hourly intervals during paddling, mid-summer drainage, final drainage and heavy rain events. During the survey, the acidity and electric conductivity (EC) of irrigation, surface drainage and subsurface drainage water, the water level of ponded water and discharge of surface drainage and subsurface drainage water were measured on site. The surface drainage, subsurface drainage, irrigation and soil water were collected during irrigation period, and the surface drainage and subsurface drainage water samples were collected at non-irrigation period too. Surface soil, fertiliser, rice, duckweed and algae as solid samples were also collected. Soil samples were obtained after basal fertilisation (nine from E1 and five from W2 in 2013;

Table 1 Agricultural practices of the experimental fields and information of the fertiliser and the rice yield

\begin{tabular}{|c|c|c|c|c|}
\hline Period & Year & Date & Activity & Note about the fertiliser and the rice yield (nitrogen content) \\
\hline \multirow{2}{*}{ Non-irrigation } & \multirow{2}{*}{2013} & Feb. - Mar. & First fertilisation & Organic fertiliser; $0.90 \% \mathrm{~N} ; 2000 \mathrm{~kg} \mathrm{ha}^{-1}$ for both fields \\
\hline & & 4 May & Basal fertilisation & Chemical fertiliser; $\mathrm{N}: \mathrm{P}: \mathrm{K}=8: 8: 8 ; 600 \mathrm{~kg} \mathrm{ha}^{-1}$ for both fields \\
\hline \multirow{4}{*}{ Irrigation } & & 21 May & Pre-flooding, paddling & \\
\hline & & 25 May & Transplanting & \\
\hline & & $18-25$ Jul. & Mid-summer drainage & \\
\hline & & 19 Sep. & Final drainage & \\
\hline \multirow{2}{*}{ Non-irrigation } & \multirow{2}{*}{$\underset{2014}{\downarrow}$} & 12 Oct. & Harvesting & Rice grain: $5406 \mathrm{~kg} \mathrm{ha}^{-1}$ in $\mathrm{E} 1(0.88 \% \mathrm{~N}) ; 5785 \mathrm{~kg} \mathrm{ha}^{-1}$ in $\mathrm{W} 2(0.90 \% \mathrm{~N})$ \\
\hline & & 4 May & Basal fertilisation & Chemical fertiliser; $\mathrm{N}: \mathrm{P}: \mathrm{K}=8: 8: 8 ; 900 \mathrm{~kg} \mathrm{ha}^{-1}$ for both fields \\
\hline \multirow{4}{*}{ Irrigation } & & 20 May & Pre-flooding, paddling & \\
\hline & & 24 May & Transplanting & \\
\hline & & $20-27$ Jul. & Mid-summer drainage & \\
\hline & & 19 Sep. & Final drainage & \\
\hline \multirow{2}{*}{ Non-irrigation } & $\downarrow$ & 11 Oct. & Harvesting & Rice grain: $5406 \mathrm{~kg} \mathrm{ha}^{-1}$ in E1 $(0.88 \% \mathrm{~N}) ; 6427 \mathrm{~kg} \mathrm{ha}^{-1}$ in $\mathrm{W} 2(0.96 \% \mathrm{~N})$ \\
\hline & 2015 & 4 May & Basal fertilisation & Chemical fertiliser; $\mathrm{N}: \mathrm{P}: \mathrm{K}=10: 12: 12 ; 727 \mathrm{~kg} \mathrm{ha}^{-1}$ for $\mathrm{E} 1,545 \mathrm{~kg}^{-1}$ for W2 \\
\hline \multirow{4}{*}{ Irrigation } & & 27 May & Pre-flooding, paddling & \\
\hline & & 31 May & Transplanting & \\
\hline & & $17-21$ Jul. & Mid-summer drainage & \\
\hline & & 23 Sep. & Final drainage & \\
\hline Non-irrigation & $\downarrow$ & 13 Oct. & Harvesting & Rice grain: $5036 \mathrm{~kg} \mathrm{ha}^{-1}$ in E1 $(0.88 \% \mathrm{~N}) ; 5727 \mathrm{~kg} \mathrm{ha}^{-1}$ in $\mathrm{W} 2(0.84 \% \mathrm{~N})$ \\
\hline
\end{tabular}


seven from E1 and three from W2 in 2014; four from E1 and four from W2 in 2015) and after harvesting (two samples from E1 and four from W2 in 2014; four from E1 and four from W2 in 2015). Fertiliser samples (one sample of organic fertiliser in 2013 and one sample of chemical fertiliser in each of the 3 years) and rice samples (four samples from E1 and four from W2 in 2013; six from E1 and four from W2 in 2014; three from E1 and four from $\mathrm{W} 2$ in 2015) were obtained from the farmer. Three samples of duckweed and algae were skimmed from an area measuring $10 \times 12 \mathrm{~cm}$ on the pond water surface in September 2018 and were further stored in plastic bags. Rainwater samples were collected 11 times in 2013 and 2015 at the University of Yamanashi $(5 \mathrm{~km}$ north of the study area). After sampling, the concentrations of dissolved total nitrogen (DTN), ammonium nitrogen $\left(\mathrm{NH}_{4}-\mathrm{N}\right)$, nitrite nitrogen $\left(\mathrm{NO}_{2}-\mathrm{N}\right)$ and nitrate nitrogen $\left(\mathrm{NO}_{3}-\mathrm{N}\right)$ in the water samples were measured, and the dissolved organic nitrogen (DON) concentration was calculated by subtracting the $\mathrm{NH}_{4}-\mathrm{N}, \mathrm{NO}_{2}-\mathrm{N}$ and $\mathrm{NO}_{3}-\mathrm{N}$ from DTN. The nitrogen content in the surface soil and rice samples and $\delta^{15} \mathrm{~N}$ in the soil samples were also measured. All the chemical analyses were conducted according to a previous report (Nguyen et al. 2015). The samples of duckweed and algae were dried over night then weighed.

The daily weather data (precipitation, temperature, wind speed and humidity) recorded at Kofu meteorological station, which is located approximately $6 \mathrm{~km}$ southwest of our study area, were obtained from the Japan Meteorological Agency (JMA 2016).

Estimation of the water balance

Water balance was estimated on a daily basis by

$\Delta W D=I+P-D-B-G-E$,

where $\triangle W D$ denotes the daily change in the water depth of the ponded water, and $I, P, D, B, G$ and $E$ denote the daily flux $\left(\mathrm{mm} \mathrm{day}^{-1}\right)$ of irrigation, precipitation, surface drainage, subsurface drainage, percolation to groundwater and evapotranspiration, respectively. $\triangle W D, D$ and $B$ were obtained by the field survey, and the values for the unobserved periods were filled by the average values of observations before and after. $E$ was calculated from the local temperature, wind speed and humidity data using the $\mathrm{ET}_{0}$ calculator version 3.1 (Food and Agriculture Organization of the
United Nation: FAO 2015). The permeability coefficient of Darcy's Law during the irrigation periods was estimated by using hourly observation $\triangle W D, D$ and $E$, that were recorded on the day without irrigation flow and precipitation. Such observation was conducted four times for E1 and five times for W2, and the calculated permeability coefficients were averaged and used for estimating total permeated water flux. $G$ during irrigation periods was then calculated by subtracting $B$ from total permeated water. $G$ during the non-irrigation periods was calculated by subtracting the total $B$ and total $E$ from $P$ in case of a rainfall event that started from December 11, 2015. Finally, $I$ was calculated based on Eq. (1) from other fluxes measured or estimated above.

\section{Estimation of the nitrogen budget}

The nitrogen budget $\left(N_{\text {budget }}\right)$ was estimated by

$$
\begin{aligned}
N_{\text {budget }}= & N_{\text {fer }}+N_{\text {irri }}+N_{\text {pre }}+N_{\text {fix }} \\
& -\left(N_{\text {rice }}+N_{\text {drain }}+N_{\text {sub }}+N_{\text {per }}\right. \\
& \left.+N_{\text {vol }}+N_{\text {den }}+N_{\text {other }}\right),
\end{aligned}
$$

where $N_{f e r}, N_{\text {irri }}, N_{\text {pre }}$ and $N_{f i x}$ denote the amounts of nitrogen inputs from fertiliser, irrigation, precipitation and biological fixation, respectively; $N_{\text {rice }}, N_{\text {drain }}, N_{\text {sub }}$, $N_{\text {per }}, N_{\text {vol }}, N_{\text {den }}$ and $N_{\text {other }}$ denote the amounts of nitrogen outputs by rice uptake, surface drainage, subsurface drainage, percolation, ammonia volatilisation, denitrification and uptake by other plants, respectively. $N_{\text {irri }}, N_{\text {pre }}, N_{\text {drain }}, N_{\text {sub }}$ and $N_{\text {per }}$ were calculated by multiplying the daily water flux with the concentration of each form of nitrogen. The concentrations in unobserved days were interpolated by the average of the observed values before and after. The nitrogen concentration in subsurface drainage was used for calculating $N_{s u b}$ with all nitrogen forms and $N_{p e r}$ with only nitrite and nitrate. The multiplication of the nitrogen content with the amount of applied fertiliser, yield of rice plant and amount of duckweed and algae generated $N_{\text {fer }}, N_{\text {rice }}$ and $N_{\text {other }}$, respectively. The nitrogen content of fertiliser and rice grain, the amount of applied fertiliser and the rice grain yield were shown in Table 1 . The ratio of straw to grain in our study were assumed as 0.96 that was the average of values in references (Ha et al. 2001; Zhang et al. 2012). The amounts (dry weight) of duckweed and algae were measured as $33 \mathrm{~g} \mathrm{~m}^{-2}$ and $0.26 \mathrm{~g} \mathrm{~m}^{-2}$, 
respectively. The values of 3.1\% (Li et al. 2009) and $3.3 \%$ (Meltem et al. 2008) were applied for the nitrogen content in duckweed and algae, respectively. $N_{f i x}$ was assumed to be $50 \mathrm{~kg} \mathrm{~N} \mathrm{ha}^{-1}$ in a crop season according to the maximum value for Azolla in the paddy fields as reported by Roger and Ladha (1992). Hayashi et al. (2006) suggested that $N_{v o l}$ depends on the amount of chemical fertiliser and $\mathrm{pH}$ value of ponded water, then they proposed volatilization ratio to the applied chemical fertiliser $(1.4 \pm 0.8 \%)$ estimated based on the experiments in lysimeter plots for paddy fields in central Japan. In this study, the $\mathrm{pH}$ value of ponded water was similar to that obtained by Hayashi et al. (2006), and the same ratio was used for the calculation of $N_{v o l}$ for each year. $N_{d e n}$ was calculated by multiplying the $\mathrm{NO}_{3}-\mathrm{N}$ concentrations in ponded water by its depths and denitrification rate constant $\left(0.13 \mathrm{day}^{-1}\right)$ that was estimated on the basis of a one-order reaction by Liang et al. (2007) for research in Jiaxing, China.

\section{Results}

Water balance

The estimated water balances are presented in Fig. 1. For inflows to E1 and W2, irrigation was observed to constitute a 30-45 times and 13-16 times larger proportion than precipitation, respectively. For outflows, percolation, surface drainage and subsurface drainage were the main components of E1. On the other hand, in outflows for W2, both of percolation and surface drainage constituted more than $40 \%$ of the total outflow and subsurface drainage constituted less than $10 \%$ of the total outflow, except for 2015. In W2 in 2015, surface drainage was considerably low

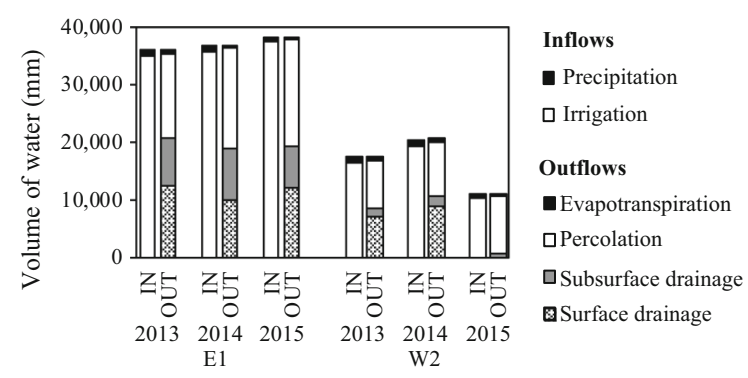

Fig. 1 The annual water balance for each rice paddy because the farmer more tightly closed the drainage gate than that in other years. Evapotranspiration was considerably small $(<3.6 \%$ of total outflow) in both the fields. The annual water flux for E1 was about twice as much $(36,010-38,035 \mathrm{~mm})$ as for W2 (11,265-20,522 mm), which exhibited high values for subsurface drainages and for percolation. In our study fields, the permeability coefficients were estimated as $196 \pm 46 \mathrm{~mm} \mathrm{day}^{-1}$ in E1 and $80 \pm 63 \mathrm{~mm} \mathrm{day}^{-1}$ in W2. A considerable water flux was thus estimated in total. Surface drainage constituted the second largest outflow, averaging $31.2 \%$ of the total outflow for E1 and $42.2 \%$ of that for W2.

Nitrogen concentrations in water samples

The nitrogen concentrations in rainwater were at lower level (DON: $0.0 \mathrm{mg} \mathrm{L}^{-1} ; \mathrm{NH}_{4}-\mathrm{N}: 0.29 \mathrm{mg} \mathrm{L}^{-1} ; \mathrm{NO}_{2}-$ $\mathrm{N}: 0.0028 \mathrm{mg} \mathrm{L}^{-1} ; \mathrm{NO}_{3}-\mathrm{N}: 0.12 \mathrm{mg} \mathrm{L}^{-1}$ ) within the range previously reported in Japan: $0.21-4.0 \mathrm{mg} \mathrm{L}^{-1}$ for $\mathrm{NO}_{3}-\mathrm{N}$ and $0.26-2.5 \mathrm{mg} \mathrm{L}^{-1}$ for $\mathrm{NH}_{4}-\mathrm{N}$ (Kyaw et al. 2005; Yoshinaga et al. 2004; Takeda et al. 1991). The temporal variations of the nitrogen concentration of each form in irrigation and in surface and the subsurface drainage obtained by analysing the water samples are depicted in Fig. 2. The maximum nitrogen concentrations in irrigation water were 1.44, 1.56 and $0.51 \mathrm{mg} \mathrm{L}{ }^{-1}$ for $\mathrm{DON}, \mathrm{NO}_{3}-\mathrm{N}$ and $\mathrm{NH}_{4}-\mathrm{N}$, respectively. In this study, $\mathrm{NO}_{2}-\mathrm{N}$ concentration was detected only two times in irrigation periods. All the forms of nitrogen except $\mathrm{NO}_{2}-\mathrm{N}$ in both surface and subsurface drainages were high at the paddling time and after paddling, they decreased rapidly. However, $\sim 0.3 \mathrm{mg} \mathrm{L}^{-1}$ of $\mathrm{NH}_{4}-\mathrm{N}$ was detected in subsurface drainage even after the paddling period, and $\mathrm{NO}_{2}-\mathrm{N}$ and $\mathrm{NO}_{3}-\mathrm{N}$ in subsurface drainage increased during the non-irrigation periods, whereas undetected or at low level during irrigation periods.

\section{Nitrogen balance}

The calculated input and output values based on nitrogen balance are depicted in Fig. 3. In case of nitrogen inputs, irrigation was constantly the largest, and the precipitation was significantly small $(<1.5 \%$ of total input) in both E1 and W2. The total input of E1 was twice as large as that of W2 because of large irrigation water flux. The outputs for E1 were distributed among rice, surface drainage, subsurface 
(a) Irrigation water

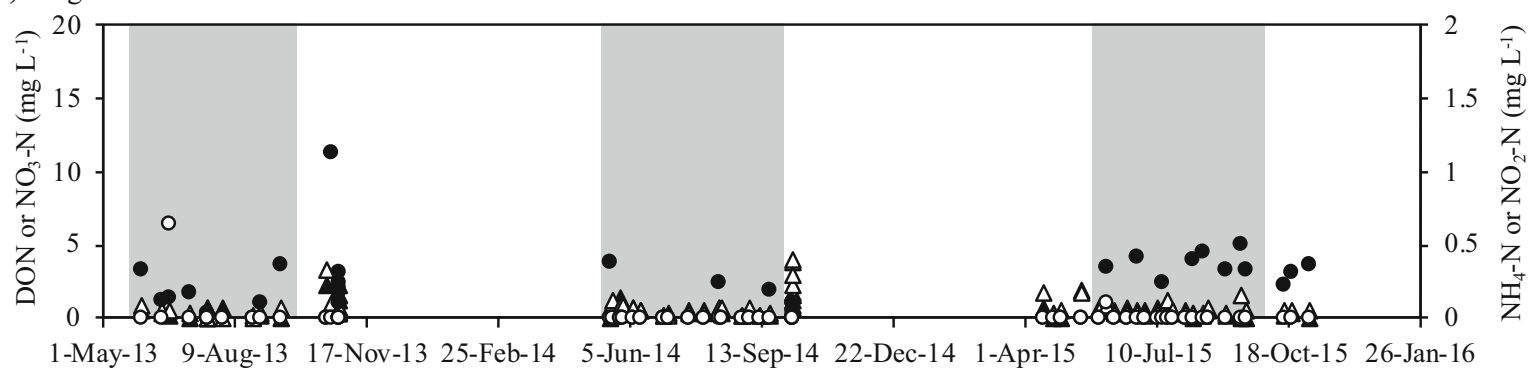

(b) Surface drainage in E1

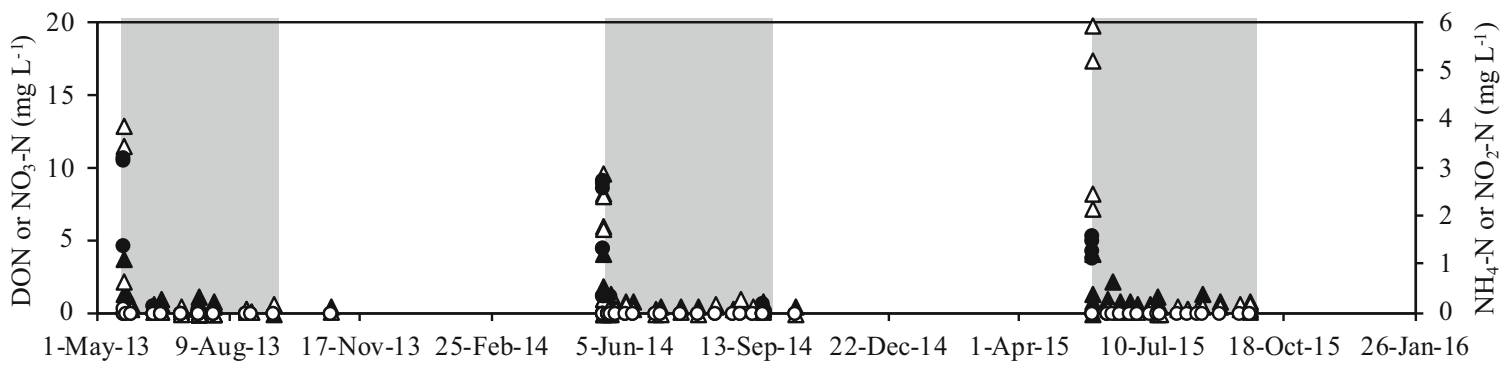

(c) Surface drainage in W2

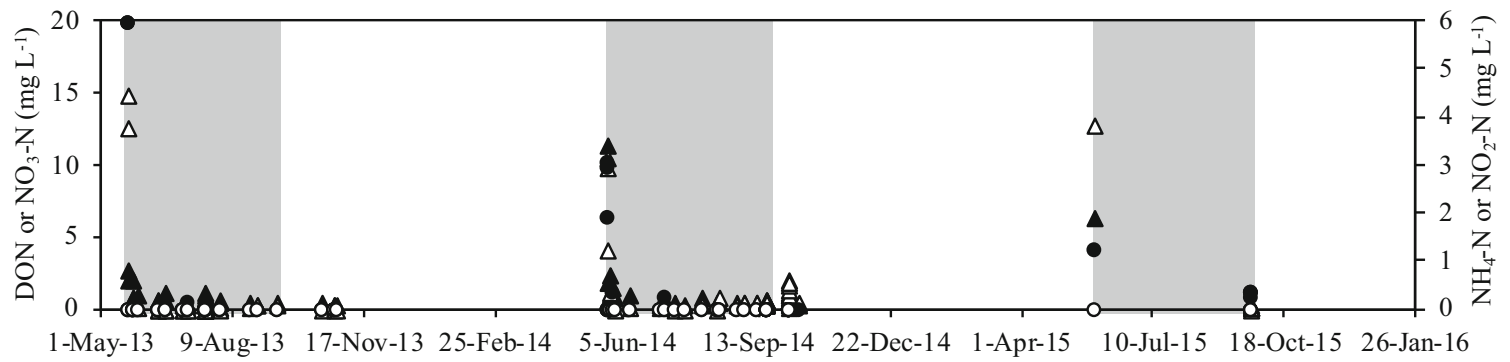

(d) Subsurface drainage in E1

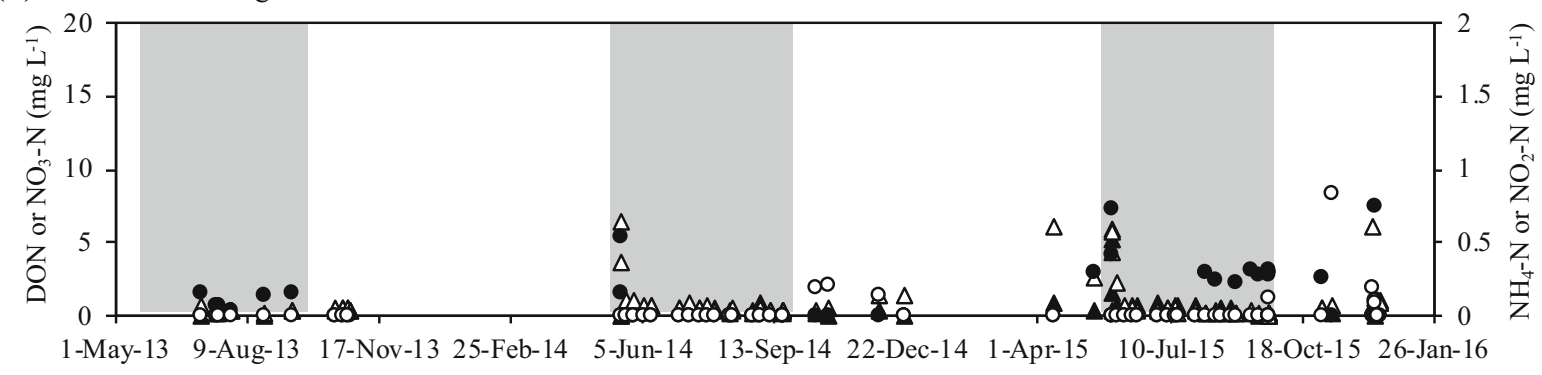

(e) Subsurface drainage in W2

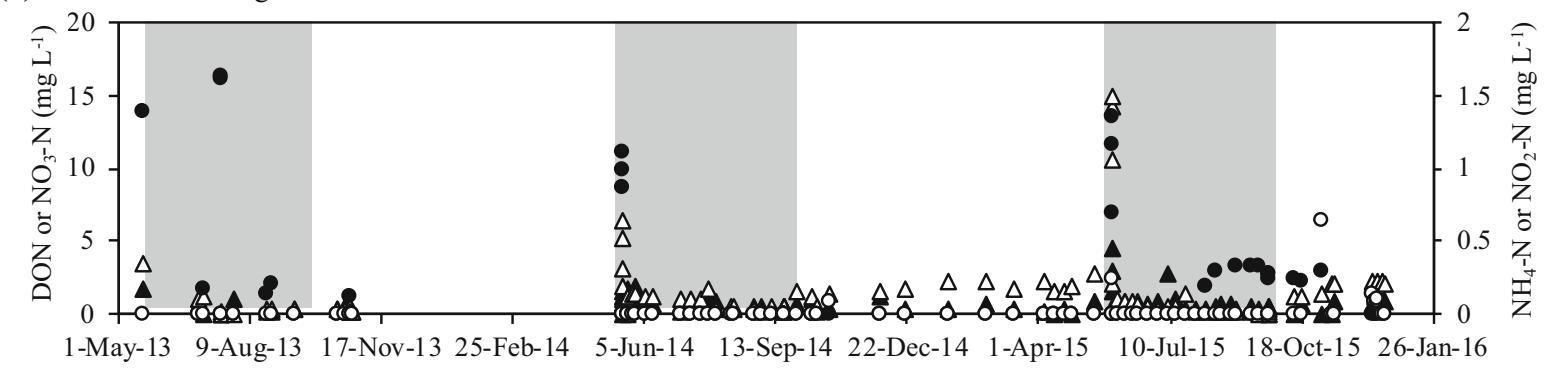


4Fig. 2 Change in nitrogen concentration for each form of nitrogen. Close triangle: DON; close circle: $\mathrm{NH} 4-\mathrm{N}$; open triangle: $\mathrm{NO} 3-\mathrm{N}$; open circle: $\mathrm{NO} 2-\mathrm{N}$; grey zone, irrigation period

drainage and percolation; the contribution of subsurface drainage for W2 was only $6.7-7.1 \%$ of the total output, and rice, drainage and percolation were observed to dominate total output of W2. The surface drainage, subsurface drainage and percolation for E1 were within $91.5-163.5 \mathrm{~kg} \mathrm{~N}^{-1}, \quad 72.4-98.3$ $\mathrm{kg} \mathrm{N} \mathrm{ha}^{-1}$ and 74.9-112.1 $\mathrm{kg} \mathrm{N} \mathrm{ha}^{-1}$, and those for W2 except for 2015 were within 78.3-113.0 $\mathrm{kg} \mathrm{N} \mathrm{ha}^{-1}, 17.5-25.1 \mathrm{~kg} \mathrm{~N} \mathrm{ha}^{-1}$ and 55.6-94.0 kg N $\mathrm{ha}^{-1}$, respectively. The percolations of $\mathrm{E} 1$ and $\mathrm{W} 2$ were similar while the nitrogen that was transported to the underground system (by subsurface drainage and percolation) in E1 (147.3-210.4 $\mathrm{kg} \mathrm{N} \mathrm{ha}^{-1}$ ) having higher water permeability was twice that observed in W2 (73.1-119.1 $\left.\mathrm{kg} \mathrm{N} \mathrm{ha}^{-1}\right)$. Nitrogen assimilated by rice in $\mathrm{E} 1\left(66.5-75.4 \mathrm{~kg} \mathrm{~N} \mathrm{ha}^{-1}\right)$ was $\sim 30 \%$ smaller than that in $\mathrm{W} 2\left(86.3-98.4 \mathrm{~kg} \mathrm{~N} \mathrm{ha}^{-1}\right)$ for all the years. The emissions to the atmosphere from both fields by volatilisation and denitrification were low. In W2 in 2015, surface drainage was considerably low due to the tight control of surface drainage water output as described before; however, the other outputs remained similar with those in 2013 and 2014. Eventually, the total output of E1 was 1.3, 1.1 and 2.3 times larger than that of W2 in 2013, 2014 and 2015, respectively.

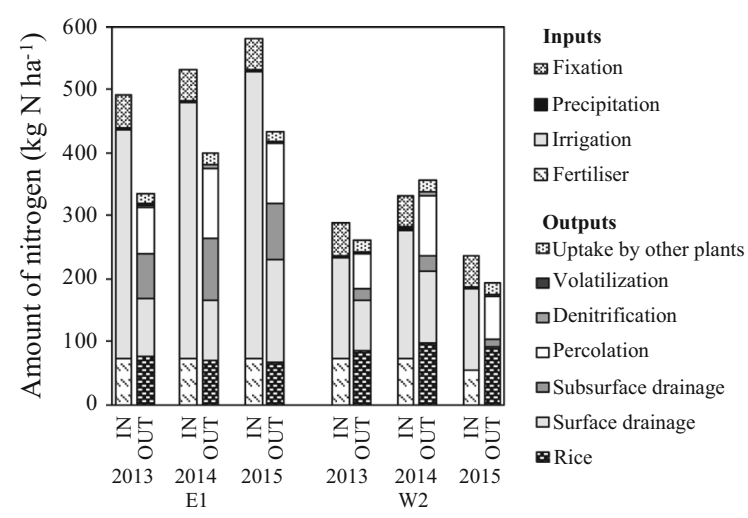

Fig. 3 The annual nitrogen budget for each paddy field

\section{Discussion}

Evaluation of water flux

Previous researchers reported ten times smaller water flux than that exhibited by this study under both stagnant irrigation and flowing irrigation (Table 2). The surface drainage fluxes for E1 and W2 were $31.2 \%$ and $42.2 \%$ of the total outflux, respectively, and were within the ranges of the previously reported values for both the two irrigation types: $29.8-45.2 \%$ of the total outflux for flowing-irrigation type and $7.9-73.4 \%$ of the total outflux for stagnant-irrigation type. The average percolation rate was $2 \mathrm{~mm} \mathrm{day}^{-1}$ as calculated by Zhao et al. (2009) and $3.25 \mathrm{~mm} \mathrm{day}^{-1}$ as observed by Cho and Han (2002) in stagnantirrigation type. In flowing-irrigation type, Takeda et al. (1991) reported the water requirement (based on evapotranspiration and percolation) to be 15-23 mm day ${ }^{-1}$, and Hama et al. (2015) estimated the percolation rate to be $30 \mathrm{~mm} \mathrm{day}^{-1}$. In our study, higher percolation rates were exhibited when compared to these previous studies $\left(139 \mathrm{~mm} \mathrm{day}^{-1}\right.$ in E1 and $76 \mathrm{~mm} \mathrm{day}^{-1}$ in $\mathrm{W} 2$ in average during the irrigation periods). The average percolation fluxes were $45.3 \%$ and $45.8 \%$ of total outflux for E1 and W2, respectively, and were also within the ranges of previous values: $42.3-66.2 \%$ of total out flux for flowing irrigation and $4.8-67.3 \%$ of total out flux for stagnant irrigation. In the flowing irrigation, the ranges for surface drainage and percolation were smaller than those in stagnant irrigation, implying the stable water discharge of not only surface drainage but also percolation under flowing condition.

\section{Characterisation of nitrogen concentration}

Hama et al. (2015) observed $\mathrm{NO}_{3}-\mathrm{N}(0.53-0.73$ $\left.\mathrm{mg} \mathrm{L}^{-1}\right)$ and Total Dissolved Nitrogen (0.7-1.7 $\mathrm{mg} \mathrm{L}^{-1}$ ) in irrigation water and $\mathrm{NH}_{4}-\mathrm{N}$ and $\mathrm{NO}_{2}-\mathrm{N}$ were below the detection limit, and the maximum DON concentration was estimated as $1 \mathrm{mg} \mathrm{L}^{-1}$. On the other hand, $\mathrm{NO}_{3}-\mathrm{N}$ and $\mathrm{NH}_{4}-\mathrm{N}$ of irrigation water were detected: average of 0.66 and $0.16 \mathrm{mg} \mathrm{L}^{-1}$ in the paddy field located near industrial park (Takeda et al. 1991). Both of the paddy fields of this study were irrigated by waters containing nitrogen concentrations within the range of those of other studies in Japan. Previous reports also showed similar 
Table 2 Water balances of paddy fields from literatures

\begin{tabular}{|c|c|c|c|c|c|c|c|c|c|c|}
\hline \multirow[t]{2}{*}{ Irrigation type } & \multicolumn{3}{|c|}{ Inflow (mm) } & \multicolumn{4}{|c|}{ Outflow (mm) } & \multirow[t]{2}{*}{ Balance $(\%)$} & \multirow{2}{*}{$\begin{array}{l}\text { Calculation } \\
\text { days (days) }\end{array}$} & \multirow[t]{2}{*}{ Literature } \\
\hline & I & $\mathrm{P}$ & Total & $\mathrm{D}$ & G & $\mathrm{E}$ & Total & & & \\
\hline \multirow[t]{7}{*}{ Stagnant } & 967 & 1510 & 2477 & 1324 & 618 & 491 & 2433 & 1.8 & 365 & Cho et al. (2000) \\
\hline & 816 & 1231 & 2048 & 1027 & 561 & 452 & 2040 & 0.4 & 294 & Cho and Han (2002)** \\
\hline & 2176 & 1595 & 3771 & 2768 & 183 & 821 & 3771 & 0.0 & 365 & Sugimoto et al. (2008)** \\
\hline & 1781 & 522 & 2303 & \multicolumn{2}{|c|}{$1699 *$} & 528 & 2227 & 3.3 & 76 & Feng et al. (2004) \\
\hline & 906 & 589 & 1495 & 255 & 808 & 463 & 1495 & 0.0 & 124 & Hama et al. (2011)** \\
\hline & 1156 & 660 & 1816 & 144 & 1222 & 451 & 1816 & 0.0 & 118 & Hitomi et al. (2007) \\
\hline & - & 750 & 750 & 502 & 201 & - & 703 & 6.2 & 138 & Zhao et al. (2012)** \\
\hline \multirow[t]{2}{*}{ Flowing } & 4007 & 509 & 4516 & 1357 & 3018 & 185 & 4560 & -1.0 & 103 & Hama et al. (2015) \\
\hline & 3735 & 926 & 4661 & 2105 & 1970 & 584 & 4659 & 0.0 & 138 & Takeda et al. (1991)** \\
\hline
\end{tabular}

*Sum of drainage and infiltration; **Average of the reported values

variations in which the nitrogen concentrations were high at the paddling time then decreased in surface drainage (Sugimoto et al. 2008; Takeda et al. 1991) and percolation (Sugimoto et al. 2008) regardless of irrigation water management type. On the other hand, during non-irrigation period, Takeda et al. (1991) reported the increase of total nitrogen and $\mathrm{NO}_{3}-\mathrm{N}$ concentrations in both subsurface drainage and percolation caused by enhancement of oxidation under dry soil condition.

Comparison of nitrogen balance between different irrigation types

The study results for nitrogen loading and nitrogen balance within the paddy fields are summarised in Table 3. According to previous reports, the total input for flowing-irrigation type was $222 \mathrm{~kg} \mathrm{~N} \mathrm{ha}^{-1}$ and was $85-270 \mathrm{~kg} \mathrm{~N} \mathrm{ha}^{-1}$ in case of stagnant-irrigation type; the nitrogen inputs for both the irrigation types were similar. In this study, the total inputs were 490-581 kg N ha ${ }^{-1}$ in E1 and 236-332 kg N ha ${ }^{-1}$ in W2 (Fig. 3). Comparing our results with the previous researches, although the water volume differed by ten times, the total input amount of nitrogen in E1 was twice as large as the reported values, and that in W2 was at upper level of reported results. The inputs through irrigation were the only factor being much larger than previous reports in both the fields. With respect to outputs, the nitrogen runoff through surface drainage was significantly higher than reported results under stagnant irrigation. Cho and Han (2002) estimated an exceptionally large amount of nitrogen in surface drainage (118.7 $\mathrm{kg} \mathrm{N} \mathrm{ha}^{-1}$ ) under stagnant irrigation in Korea, in which the total nitrogen remained at higher concentration level in ponded water and eventually in surface drainage water after fertilisation than that obtained in our study under flowing irrigation. The subsurface drainage was reported as $39.4-47.7 \mathrm{~kg} \mathrm{~N} \mathrm{ha}^{-1}$ under stagnant irrigation only by Takakai et al. (2017). In this study under flowing irrigation, the nitrogen loss by subsurface drainage ranged from $21.3 \mathrm{~kg} \mathrm{~N} \mathrm{ha}^{-1}$ in W2 to $86.9 \mathrm{~kg} \mathrm{~N} \mathrm{ha}^{-1}$ in E1. These results imply that the irrigation type, i.e. flowing and stagnant irrigation, does not simply affect the nitrogen loading, controlled by both nitrogen concentration and water flux, through surface drainage and subsurface drainage. The output of percolation was similar to that observed in a previous report under flowing irrigation (Takeda et al. 1991), and higher than those under stagnant irrigation. As the result, the total output amounts of nitrogen in the present study were estimated to be at maximum level compared to the reported values, owing to contribution of large water flux under flowing irrigation.

In other studies listed in Table 3, nitrogen balances are evaluated with multiple inputs and outputs of waterflow, rice uptake and air emissions. The rice uptake was not considered as a major contributor to total nitrogen outputs by Takeda et al. (1991), Cho and Han (2002), Sugimoto et al. (2008) and Zhao et al. (2012). These studies did not account for the nitrogen assimilated by rice because they focused only on the 


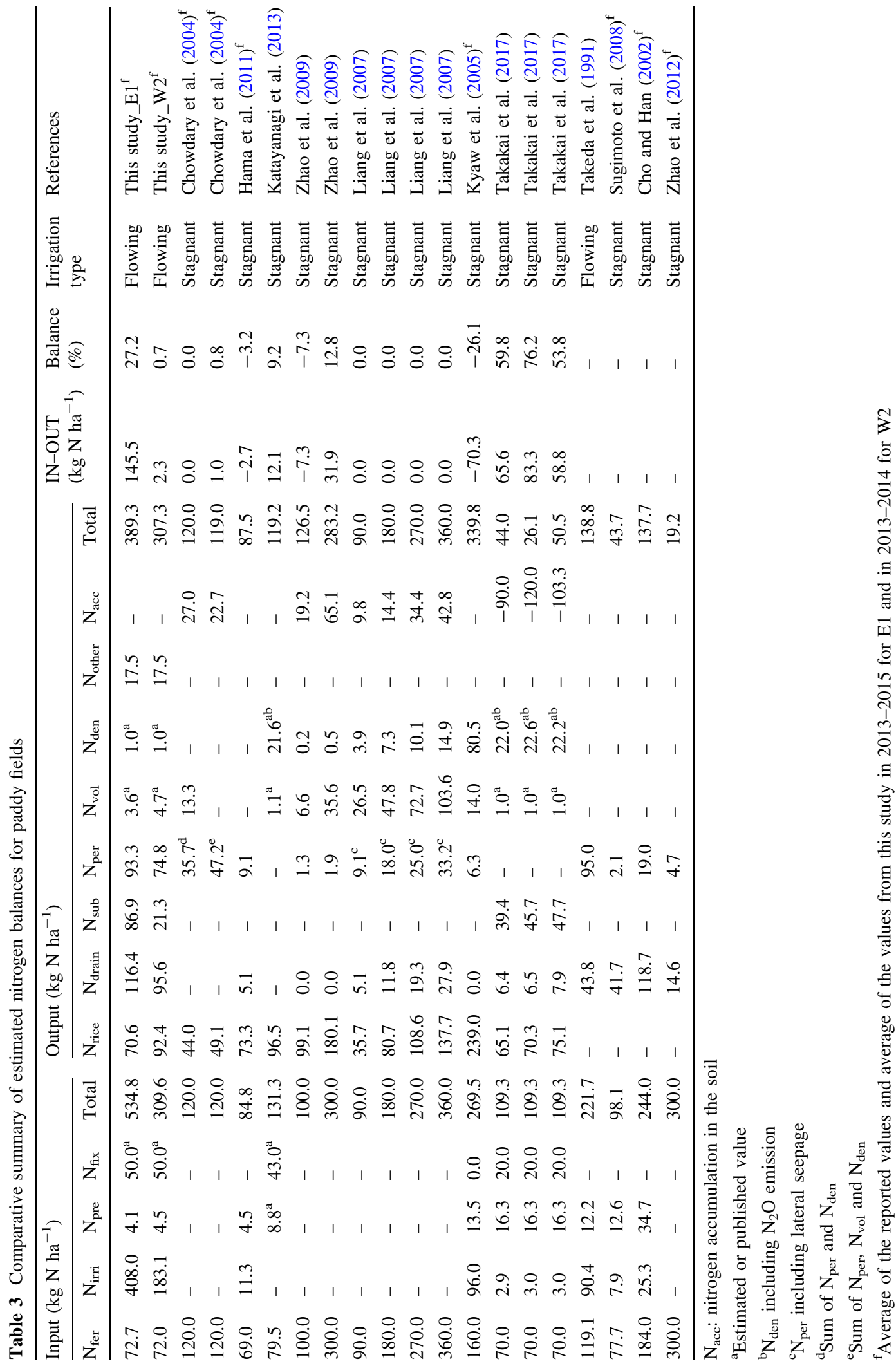


estimation of nitrogen loading by water flows. Additionally, the uptake by other plants was not considered in all of the previous reports which studied nitrogen balance in paddy field. In Kyaw et al. (2005), there was a large negative balance between the total input and the total output because of the high nitrogen removal capacity owing to the high nitrogen uptake by the whole rice plant body, high denitrification activity and low water flow to avoid surface water drainage. In our study, to the contrary, the large positive balance was found in E1. We assumed these differences to be attributed to the accumulation in the soil, because we considered the conceivable other major factors for outputs. The amount of accumulated nitrogen was estimated to be $27.2 \%$ of the total input for E1 and $0.7 \%$ of that for $\mathrm{W} 2$ by performing nitrogen budget analyses. Takakai et al. (2017) studied the nitrogen loss in a field with upland-paddy rotation and different histories of manure application by measuring the change in the soil nitrogen content and found soil nitrogen was significantly decreasing. To the contrary, Zhao et al. (2009) observed the positive amount of residual nitrogen $(19.2 \%$ and $21.7 \%$ of chemical fertiliser) determined using the ${ }^{15} \mathrm{~N}$ tracing method with rice-wheat rotation in China. In addition, Chowdary et al. (2004) and Liang et al. (2007) also reported the nitrogen left in the soil as $8-20 \%$ of the total input with a balanced nitrogen amount. Compared with these positive accumulations, our nitrogen balance attributed to soil accumulation in E1 was relatively larger. For identifying the soil characteristics, we measured the nitrogen contents and stable isotope ratios (Fig. 4). The isotope ratios of the surface soil nitrogen were slightly different $(p<0.05)$. The nitrogen content in the surface soil, however, was demonstrated to be significantly different $(p<0.01)$ between E1 and W2: higher in E1 than in W2 implying the higher potential of soil adsorption in E1, and it showed the increasing tendency during the period of our experiment in the both field. In addition, the depth of the ploughed soil in E1 $(55 \mathrm{~cm})$ was greater than that in W2 $(10 \mathrm{~cm})$, and it may also cause the significant nitrogen accumulation in E1. Previous studies have reported that the accumulation rate observed in a field would increase with increasing application of chemical fertilisers (Liang et al. 2007; Zhao et al. 2009). However, E1 exhibited a higher accumulation than other studies in Table 3, in some of which the amount of applied fertiliser is much higher

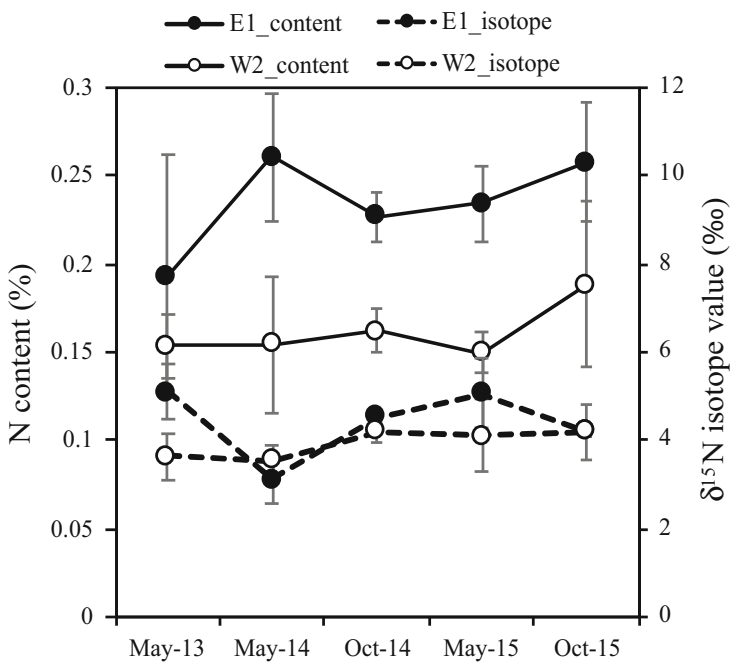

Fig. 4 Changes in nitrogen content and in the $\delta^{15} \mathrm{~N}$ isotope value of soil for each paddy field

than that in E1. With respect to total input, E1 was largest because of high nitrogen input by flowing irrigation. The nitrogen accumulation in soil may be enhanced not only by the amount of applied fertiliser but also by the water flow characteristics.

\section{Conclusions}

In this study, the nitrogen balances for two paddy fields were estimated under flowing-irrigation condition using four factors as inputs and seven factors as outputs. The observed fields exhibited high percolation rates because of the installation of subsurface drainage. The calculated annual water flows were observed to be more than 10 times larger than that observed in previous reports. Regarding the changes in nitrogen concentration in water over time, it rapidly decreased after paddling in both surface and subsurface drainage waters. The $\mathrm{NO}_{3}-\mathrm{N}$ and DON concentrations constituted $43 \%$ and $47 \%$ of the dissolved nitrogen in irrigation water, respectively. Furthermore, the $\mathrm{NH}_{4}-\mathrm{N}$ concentration was also detected even though majority of the previous studies did not detect it in irrigation water. The sizes of the nitrogen balances were near the higher levels or much higher than the levels that were reported in previous studies. Notably, there was a large difference in nitrogen input via irrigation water between our study and previous 
studies. The nitrogen balances in our study fields showed large difference between the total input and the total output: the positive balance was considered to be caused by not taking nitrogen accumulation in soil into account. According to previous researchers, the nitrogen remaining in the soil was related to the amount of applied fertiliser. However, the fertiliser rates in our study fields were not higher level compared with the experimental fields in other studies. Therefore, in addition to effect of fertilizer application, the effect of nitrogen input via water flow on soil accumulation as well as nitrogen discharge to water environment is to be assessed by evaluating the nitrogen balances for better control of environmental quality.

Acknowledgements We are grateful to Mr. Okamoto Takehiro for his help in the field as well as in the laboratory. We are also grateful to Dr. Ishidaira Hiroshi and Dr. Nakamura Takashi for assessing the research methodology. We would like to thank Mr. Otogro Kohsi for kindly providing access to his paddy fields. This study was financially supported by Grant-inAid for Scientific Research (No. 15K06270) from Japan Society for the Promotion of Science (JSPS) and by Support for Reginal Research from University of Yamanashi.

Open Access This article is licensed under a Creative Commons Attribution 4.0 International License, which permits use, sharing, adaptation, distribution and reproduction in any medium or format, as long as you give appropriate credit to the original author(s) and the source, provide a link to the Creative Commons licence, and indicate if changes were made. The images or other third party material in this article are included in the article's Creative Commons licence, unless indicated otherwise in a credit line to the material. If material is not included in the article's Creative Commons licence and your intended use is not permitted by statutory regulation or exceeds the permitted use, you will need to obtain permission directly from the copyright holder. To view a copy of this licence, visit http://creativecommons.org/licenses/by/4.0/.

\section{References}

Antonopoulos VZ (2010) Modelling of water and nitrogen balances in the ponded water and soil profile of rice fields in Northern Greece. Agric Water Manag 98:321-330. https:// doi.org/10.1016/j.agwat.2010.08.026

Cho JY, Han KW (2002) Nutrient losses from paddy field plot in central Korea. Water Air Soil Pollut 134:215-228. https:// doi.org/10.1023/A:1014119807982

Cho JY, Han KW, Choi JK (2000) Balance of nitrogen and phosphorus in a paddy field of Central Korea. Soil Sci Plant Nutr 46(2):343-354. https://doi.org/10.1080/00380768. 2000.10408789
Chowdary VM, Rao NH, Sarma PBS (2004) A coupled soil water and nitrogen balance model for flooded rice fields in India. Agric Ecosyst Environ 103:425-441. https://doi.org/ 10.1016/j.agee.2003.12.001

FAO (2015) ET0 Calculator. FAO Databases \& Software. http:// www.fao.org/land-water/databases-and-software/etocalculator/en/. Accessed 16 October 2015

Feng YW, Yoshinaga I, Shiratani E, Hitomi T, Hssebe H (2004) Characteristics and behaviour of nutrients in a paddy field area equipped with a recycling irrigation system. Agric Water Manag 68:47-60. https://doi.org/10.1016/j.agwat. 2004.02.012

Guo HY, Zhu JG, Wang XR, Wu ZH, Zhang Z (2004) Case study on nitrogen and phosphorus emissions from paddy field in Taihu region. Environ Geochem Health 26:209-219. https://doi.org/10.1023/B:EGAH. 0000039583.71423.b4

Ha SR, Dung PA, Lee BH (2001) Impacts of agrochemical fertilizer on the aquatic environment of paddy fields in Vietnam. Water Sci Technol 43(5):193-202

Hama T, Nakamura H, Kawashima S, Kaneki R, Mitsuno T (2011) Effects of cyclic irrigation on water and nitrogen mass balances in a paddy field. Ecol Eng 37:1563-1566. https://doi.org/10.1016/j.ecoleng.2011.03.032

Hama T, Jikumuru C, Kobayashi T, Kawagoshi Y, Shima T, Fujimi T (2015) Potential of groundwater recharge and nitrogen removal by a paddy field in the middle area Shirakawa River Watershed in Kumamoto. IDRE J 299:II_89II_93. https://doi.org/10.11408/jsidre.83.ii_89 (in Japanese)

Haruta S, Sudo M, Eguchi S, Okubo T, Kuroda H, Takeda I, Fujiwara T, Yamamoto T, Hitomi T, Shiratani E, Yokota K, Inoue T (2015) Effluent N, P and COD loads from paddy fields in Japan: a critical review. J Jpn Soc Water Environ 38(4):81-91. https://doi.org/10.2965/jswe.38.81 (in Japanese)

Hayashi K, Seiichi Nishimura S, Yagi K (2006) Ammonia volatilization from the surface of a Japanese paddy field during rice cultivation. Soil Sci Plant Nutr 52:545-555. https://doi.org/10.1111/j.1747-0765.2006.00053.x

Hitomi T, Yoshinaga I, Miura A, Hamada K, Shiratani E, Takaki K (2007) Research for effluent of DOM and hydrophobic acids from a paddy field. Trans JSIDRE 250:73-81. https:// doi.org/10.11408/jsidre2007.2007.419 (in Japanese)

Ishii S, Ikeda S, Minamisawa K, Senoo K (2011) Nitrogen cycling in rice paddy environments: past achievements and future challenges. Microbes Environ 26(4):282-292. https://doi.org/10.1264/jsme2.ME11293

JMA (2016) The recorded weather data and download. JMA. https://www.data.jma.go.jp/gmd/risk/obsdl/index.php. Accessed 23 Jan 2016

JSIDRE (2001) Science for natural clean water in agricultural area. JSIDRE, Japan (in Japanese)

Katayanagi N, Ono K, Fumoto T, Mano M, Miyata A, Hayashi K (2013) Validation of the DNDC-Rice model to discover problems in evaluating the nitrogen balance at a paddyfield scale for single-cropping of rice. Nutr Cycl Agroecosyst 95(2):255-268. https://doi.org/10.1007/s10705013-9561-1

Kyaw KM, Toyota K, Okazaki M, Motobayashi T, Tanaka H (2005) Nitrogen balanace in a paddy field planted with 
whole crop rice (Oryza sative cv. Kusahonami) during two rice-growing season. Biol Fertil Soils 42:72-82. https:// doi.org/10.1007/s00374-005-0856-5

Li H, Liang X, Lian Y, Chen LXY (2009) Reduction of ammonia volatilization from urea by a floating duckweed in flooded rice field. Nutr Manag Soil Plant Anal 73(6):1890-1895. https://doi.org/10.2136/sssaj2008.0230

Liang XQ, Chen YX, Li H, Tian GM, Zhang ZJ, Ni WZ, He MM (2007) Nitrogen interception in floodwater of rice in Taihu region of China. J Environ Sci 19:1474-1481. https://doi. org/10.1016/S1001-0742(07)60240-X

Meltem UD, Chakkrid S, Krishna RP (2008) Bioavailability of dissolved organic nitrogen in treated effluents. Water Environ Res 80(5):397-406. https://doi.org/10.2175/ 106143007X221454

Morita S (2008) Prospect for developing measures to prevent high-temperature damage to rice grain ripening. Jpn J Crop Sci 77(1):1-12. https://doi.org/10.1626/jcs.77.1 (in Japanese)

Nguyen TPM, Nakamura T, Shindo J, Nishida K (2015) Application of stable isotopes to identify nitrogen sources in the outflow waters from paddy. J Water Environ Technol 13(5):371-381. https://doi.org/10.2965/jwet.2015.371

Nishida K, Uo T, Yoshida S, Tsukaguchi T (2015) Effect of water depth, amount of irrigation water, and irrigation timing on water temperature in paddy field during continuous irrigation with cool running-water. JSIDRE J 300:I_185-I_194 (in Japanese)

Roger PA, Ladha JK (1992) Biological N 2 Fixation in wetland rice fields: estimation and contribution to nitrogen balance. Plant Soil 141:41-55

Shinozuka K, Chiwa M, Nakamura K, Nagao S, Kume A (2016) Stream water nitrogen eutrophication during non-irrigated periods in a paddy-dominated agricultural basin in a snowfall aria in Japan. Water Air Soil Pollut 227:2219. https://doi.org/10.1007/s11270-016-2906-Z

Sugimoto Y, Komai Y, Kunimatsu T (2008) Evaluation of loading rate of nitrogen from rice-paddy by small watershed method. J Water Technol 6(2):113-126

Takakai F, Kikuch T, Sato T, Takeda M, Sato K, Nakagawa S, Kon K, Sato T, Kaneta Y (2017) Changes in the nitrogen budget and soil nitrogen in a field with paddy-upland rotation with different histories of manure application. Agriculture 7(39). https://doi.org/10.3390/agriculture705 0039
Takeda I, Kunimatsu T, Kobayashi S, Maruyama T (1991) Pollutants balance of a paddy field area and its loadings in the water system-studies on pollution loading from a paddy field area (II). Trans JSIDRE 153:63-72. https://doi. org/10.11408/jsidre1965.1991.153_63 (in Japanese)

Yamazaki T, Ishikawa S, Nagasaka S, Sasada K, Kohno E (2013) Research study on the water quality purification function of paddy fields regarding differences in irrigation method and farmland utilization. J Jp Soc Civil Eng 69(4):183-195 (in Japanese)

Yoshinaga I, Feng Y, Singh RK, Shiratani E (2004) Dissolved nitrogen model for paddy field ponded water during irrigation period. Paddy Water Environ, 2:145-152. https:// doi.org/10.1007/s10333-004-0053-4

Yoshinaga I, Miura A, Hitomi T, Hamada K, Shiratani E (2007) Runoff nitrogen from a large sized paddy field during a crop period. Agric Water Manag 87:217-222. https://doi. org/10.1016/j.agwat.2006.06.020

Zhang Q, Yang A, Zhang H, Yi J (2012) Recovery efficiency and loss of $15 \mathrm{~N}$-labelled urea in a rice-soil system in the upper reaches of the Yellow River basin. Agric Ecosyst Environ 158:118-126. https://doi.org/10.1016/j.agee. 2012.06.003

Zhang JH, Liu JL, Zhang JB, Cheng YN, Wang WP (2013) Nitrate-nitrogen dynamics and nitrogen budgets in ricewheat rotation in Taihu Lake region, China. Pedosphere 23(1):59-69. https://doi.org/10.1016/S1002-0160(12) 60080-0

Zhao X, Xie YX, Xioung ZQ, Yan XY, Xing GX, Zhu ZL (2009) Nitrogen fate and environmental consequence in paddy soil under rice-wheat rotation in the Taihu lake region, China. Plant Soil 319:225-234. https://doi.org/10. 1007/s11104-008-9865-0

Zhao X, Zhou Y, Min J, Wang S, Shi W, Xing G (2012) Nitrogen runoff dominates water nitrogen pollution from rice-wheat rotation in the Taihu Lake region of China. Agric Ecosyst Environ 156:1-11. https://doi.org/10.1016/j.agee.2012.04. 024

Publisher's Note Springer Nature remains neutral with regard to jurisdictional claims in published maps and institutional affiliations. 